\title{
Changes in eating attitudes and behaviours in a sample of female university students studying health degrees: a 12-months follow-up study
}

Tetyana Rocks*, Fiona Pelly, Lisa Martin, Gary Slater

From 2015 ANZAED Conference: Riding the Waves to Recovery

Surfers Paradise, Australia. 21-22 August 2015

It remains unclear if studying a health-related degree alters an individual's eating attitudes and diet-related behaviours. This study explored changes in eating attitudes and behaviours in 36 female students (mean age $28.6 \pm 10.0$ years) enrolled in health degrees (Nutrition and Dietetics, $n=26$; Occupational Therapy, $n=10$ ) over a year of their undergraduate studies. Participants were asked to complete several self-reported questionnaires, including the Eating Attitudes Test (EAT-26), the Three-Factor Eating Questionnaire (TFEQ-R18), the Rosenberg's Self-Esteem Scale, and the Body Shape Questionnaire (BSQ-8D) that assessed their demographic, anthropometric, dietary, body satisfaction and self-esteem related characteristics in September-October 2013 and again 12 months later. Results suggest a significant decrease in eating disorder risk and body dissatisfaction, with an increase in self-esteem. However, the participants' weight, cognitive restraint, uncontrolled eating and emotional eating remained stable. The associations between the explored characteristics will be presented on a group and individual level. Possible directions for future research in this population will be outlined.

Submit your next manuscript to BioMed Central and take full advantage of:

- Convenient online submission

- Thorough peer review

- No space constraints or color figure charges

- Immediate publication on acceptance

- Inclusion in PubMed, CAS, Scopus and Google Scholar

- Research which is freely available for redistribution
C Biomed Central

* Correspondence: tetyana.rocks@research.usc.edu.au

University of the Sunshine Coast, Sunshine Coast, Australia 